\title{
EMERGÊNCIA PRISIONAL NO GRÃO-PARÁ: discussões sobre as cadeias em tempos de Cabanagem (1830-1845)
}

\author{
Thiago Broni de Mesquita* \\ João Victor da Silva Furtado**
}

\begin{abstract}
RESUMO: Depois de realizado o processo de independência, a organização do Estado Nacional passa a ser preocupação principal para as elites imperiais. Nas primeiras décadas que sucedem o processo de emancipação são executadas medidas legislativas intimamente ligadas ao processo de consolidação do Estado Nação. Nesse sentido, o primeiro Código Criminal do Império da década de 1830, bem como o movimento de independência apresentavam características liberais e constitucionalistas, servindo tanto para por em desuso as leis da antiga metrópole, quanto para colocar em prática novas maneiras de punição, no qual as cadeias ganham destaque. O objetivo deste artigo é o contexto de emergência prisional no Pará durante o pós-Cabanagem, analisando as medidas executadas pelas autoridades provinciais voltadas para políticas de coerção e encarceramento.
\end{abstract}

PALAVRAS-CHAVE: Cabanagem; Cárcere; Estado Nacional.

\section{Prison emergency in Grão-Pará: discussions about jails in Cabanagem times (1830 - 1845)}

\begin{abstract}
After performing the process of independence, the organization of the national state becomes the primary concern for the imperial elites. In the first decades that follows the emancipation process legislative measures were implemented closely linked to the process of consolidation of the nation state. In this sense, the first 1830s the Empire Criminal Code as well as the independence movement had liberal and constitutionalist characteristics, serving both to put into disuse the laws of former colonial power, and to put into practice new ways of punishment, in which the jails were highlighted. The purpose of this article is the prison emergency context in Pará during the postCabanagem, analyzing the measures implemented by the provincial authorities focused on enforcement and incarceration politcs.
\end{abstract}

KEYWORDS: Cabanagem; Prison; Government.

\section{Emergencia de la prisión en Grão-Pará: debates sobre las cárceles en los tiempos de la Cabanagem (1830 - 1845)}

RESUMEN: Después de hecho el proceso de la independencia, la organización del Estado nacional se convertió en la principal preocupación de las élites imperiales. En las primeras décadas que se siguen al proceso de emancipación se pusieron en marcha medidas legislativas estrechamente vinculadas ala consolidación del Estado-nación. En este sentido, el primer Código Penal del Imperio en la década de 1830, bien como el movimiento de independencia tuvieron características liberales y constitucionalistas, que sirvieron tanto para poner en desuso las leyes de la antigua metrópolis, como para poner en práctica nuevas formas de castigo, entreellas se destacan las cárceles. El propósito de este artículo es discutir el contexto de la emergencia de la prisión en Pará durante el post-Cabanagem, analizando las medidas adoptadas por las autoridades provinciales dirigidas a las políticas de coerción y de encarcelamiento.

PALABRAS-CLAVE: Cabanagem; Prisión; Gobierno.

* Professor substituto em História da Amazônia na Universidade Federal do Pará. Doutorando em História Social pela Universidade Federal do Rio de Janeiro. Email: thiagobroni@yahoo.com.br.

** Graduando do Curso de História pela Faculdade de História da Universidade Federal do Pará - Campus Bragança. 


\section{Independência e Código criminal: prisões como modernidade}

A palavra "prisão" no contexto parece estar presente em toda a história das sociedades ocidentais e ao longo do tempo ganhou sentidos diversos. No século XIX num contexto penitenciário e dentro de um projeto civilizatório responde especialmente a uma lógica de segregação das interações sociais e isolamento para que assim o preso possa refletir sobre seus atos e ser punido.

Nem sempre as prisões foram a penalidade por excelência, de modo que se levarmos em consideração os seus usos durante a antiguidade perceberemos que as penalidades eram executadas baseadas em princípios corretivos e não penais, ou seja, com a prisão buscava-se assegurar a integridade física do preso até o julgamento e aplicação da pena, interessante notar que nesse momento não é possível definir os tipos de estabelecimentos nos quais o apenado era mantido ${ }^{1}$.

Durante o século XIII, ao analisar as mudanças na agressividade, Norbert Elias ${ }^{2}$ afirma que não havia um poder social punitivo definido e em um contexto de guerra e prisão dos vencidos em batalha, destaca que o único medo que poderia haver era exatamente o de estar do lado vencido por um adversário mais forte, pois dentro dessa relação o que imperava eram as explosões de crueldade, da qual ninguém estava excluído. Para Elias o prazer de matar e torturar era socialmente permitido. Segundo o autor:

O que, por exemplo, devia ser feito com prisioneiros? Era pouco o dinheiro nessa sociedade. Se os prisioneiros podiam pagar e, além disso, eram membros da mesma classe do vitorioso, exercia-se certo grau de contenção. Mas, os outros? Conserválos vivos significava alimentá-los. Devolvê-los significava aumentar a riqueza e o poder de luta do inimigo. (...). De modo que os prisioneiros eram mortos ou devolvidos tão mutilados que não prestavam mais para o serviço de guerra ou trabalho. $^{3}$

Durante a idade média temos o avanço da prisão de Estado e a prisão eclesiástica, baseadas no princípio de custódia, meditação e penitência. Ao fazer um balanço historiográfico para compreender as origens da pena de prisão, Tatiana Chiaverini ${ }^{4}$ destaca as questões que envolviam os conflitos de interesse e o surgimento de leis que resguardavam direitos sobre o feudo, a ideia de paz social e o medo. Segundo Chiaverini ${ }^{5}$ :

Com a descentralização do poder político, o sistema de punição estatal se tornou impraticável, passando a existir a lei do feudo e a pena pecuniária. A ausência de um poder central forte permitia que qualquer conflito de interesses ameaçasse a paz social, na medida em que parentes e súditos eram automaticamente envolvidos nesses conflitos. "A principal dissuasão para o crime era o medo da vingança pessoal da parte injuriada. O crime era visto como uma ação de guerra". 
A preocupação básica do direito penal, portanto, passou a ser a preservação da paz, conseguida através da arbitragem privada e da imposição de fianças. A composição pecuniária e a fiança foram os métodos de punição preferidos na Idade Média, mas foram gradativamente substituídos pela punição corporal e a pena de morte, que, por sua vez, em torno do século XVII, cederam espaço à prisão. Essas mudanças nos métodos punitivos têm relação direta com as diferentes fases do desenvolvimento econômico e social.

A Igreja é uma importante instituição a desenvolver um sistema punitivo, durante a Idade Média, baseado no encarceramento, adotando o confinamento individual como pena, na qual esta possuía um caráter de penitência e meditação. Para César Bittencourt ${ }^{6}$ esse sistema entre outras coisas visava a regeneração pelo remorso e arrependimento, com sofrimento, solidão, mutilação e outros meios pelos quais a alma do delinquente se purificaria do pecado. Nesse sentido, o surgimento do Santo Ofício da Inquisição, por exemplo, estava ligado à necessidade de criação de um poder punitivo, para combater o crescente número de infieis no início do século XIII.

Em "Medo, reverência e terror: reler Hobbes hoje", o historiador Carlo Ginzburg 7 fala da atualidade do terror e chama o leitor a um olhar à distância, através daquilo que ele define como "luneta invertida", para isso ele recorre a obra do teórico inglês Thomas Hobbes para demonstrar aspectos relativos ao medo, aos elementos da lei, o estado de natureza e o surgimento do Estado. Sobre o estado de natureza, assevera Ginzburg ${ }^{8}$ :

Em tal estado, os homens são substancialmente iguais e têm os mesmos direitos (entre os quais o de ofender e de se defender): por isso vivem numa condição de guerra perene, de "desconfiança geral", de "medo recíproco". Eles saem dessa situação intolerável renunciando a uma parte dos próprios direitos: um pacto transforma uma multidão amorfa num corpo político. Nasce assim o Estado, aquele que Hobbes chamará Leviatã.

Ao avançar em sua análise sobre a obra de Thomas Hobbes, o autor destaca aspectos importantes naquilo que se referia a religião e o surgimento do Estado moderno, de modo que para Ginzburg, não há em Hobbes a intenção de destruir a religião vista como imaginação, mas compreender a partir da formulação de um paradoxo apresentado por Tácito, como "a religião, fruto do medo e da imaginação humana, pode funcionar”.

Portanto, seja no caso da origem da religião, seja no da origem do Estado, encontramos no início o medo (feare) e, no fim, como resultado a sujeição ou reverência (awe). No meio, a ficção, que se impõem aqueles que a criaram uma realidade: "Está é a fundação daquele grande Leviatã, ou melhor, para falar com mais reverência, daquele Deus mortal a quem, abaixo do Deus imortal, somos devedores de nossa paz e defesa". 9 
Percebemos, portanto, uma relação direta entre Estado e religião, entre medo e reverência, entre lei e punição. Nesse contexto, Bittencourt afirma que haverá um longo processo de transição e dessacralização da punição entre os séculos XV e XVIII, restando em muitos casos de resquícios feudais e católicos, produtos dessa "mística" ou imbricamento do surgimento do Estado moderno e a força da religião e da igreja católica durante a idade média.

A privação da liberdade, como pena por excelência parece corresponder aos séculos XVIII e XIX, processo que possui intrínseca relação com as revoluções da época, principalmente com os ideais do liberalismo. Neste contexto, serviam como prisões, segundo Bittencourt:

Os lugares que mantinham os acusados até a celebração do julgamento eram bem diversos, já que naquela época não existia ainda uma arquitetura penitenciária própria. Os piores lugares eram empregados como prisões: utilizavam-se horrendos calabouços, aposentos frequentemente em ruínas ou insalubres de castelos, torres, conventos abandonados, palácios e outros edifícios. ${ }^{10}$

Para Michel Foucault ${ }^{11}$ os séculos XVIII e XIX foram marcados por discussões e reformas de caráter penitenciário nos Estados Unidos e na Europa, imbuídos num ideal de modernidade. Segundo Foucault:

É a época em que foi redistribuída na Europa e nos Estados Unidos, toda a economia do castigo. Época de grandes "escândalos" para a justiça tradicional, época dos inúmeros projetos de reformas, nova teoria da lei e do crime, nova justificação moral ou política do direito de punir; abolição das antigas ordenanças, supressão dos costumes; projetos ou redação de códigos "modernos": Rússia, 1769; Prússia, 1780; Pensilvânia e Toscana, 1786; Áustria, 1788; França, 1791, Ano IV, 1808 e 1810. Para a justiça penal, uma nova era.

Os debates sobre reformas prisionais que ocorreram durante os séculos XVIII e XIX na Europa e nos Estados Unidos impulsionaram a construção de instituições de caráter penitenciário, tais como cadeias e casas de correção sob um discurso de reinserção do criminoso à sociedade, que seria alcançado através da privação da liberdade e do hábito do trabalho, representando uma maneira moderna de resolver questões criminais em oposição ao suplício e as antigas e obsoletas Ordenações, sendo assim, a construção de cadeias representava modernização e urbanização, ainda que as condições de vida dos presos não fossem favoráveis.

Nesse ponto é importante destacar que os termos "penitenciária", ou mesmo "reforma prisional" são datados e fazem parte de um projeto civilizatório que abarca o século XIX, conforme afirmamos anteriormente. Geraldo Ribeiro de Sá ${ }^{12}$ destaca nesse contexto o modelo prisional adotado na Filadélfia (EUA) em 1790, onde a principal característica era a total 
reclusão do preso durante o período de condenação, restando o exame de consciência dentro de uma arquitetura de isolamento dos demais indivíduos.

No caso europeu do século XIX, Isabel Pojo do Rego ${ }^{13}$ evidência questões importantes dentro de uma conjuntura sociológica, onde a questão legal da pena nem sempre é respeitada e obedece a uma série de arbítrios, para a autora a prisão das classes "perigosas" corresponde aos anseios de uma elite dirigente que ao defender e impor ideais democráticos, vê na pena de prisão uma forma de controle social dentro de uma lógica elitista de defesa da propriedade privada.

Para a autora, são impostos sentidos sociais de diferentes formas de encarceramento e distingue estas de acordo com seus sentidos, que podem ser os de neutralização, de diferenciação social ou ressocialização e, por fim, o de autoridade, o que visa afirmar uma relação de poder $^{14}$. Para Rego, no contexto francês, tipos de espaços prisionais são estabelecidos visando corresponder as formas de encarceramento. Segundo a autora:

Três tipos principais de espaço prisional, na França, são por Combessie identificados. O primeiro é a delegacia, que acolhe os presos provisórios. A penitenciária, denominada na França por maison centrale, é o segundo tipo de espaço "destinado ao condenado à pena de reclusão, em regime fechado". Neste caso, dois modelos de penitenciária representam tipos ideais clássicos: o da Pensilvânia e o de Auburn, baseados no sistema de isolamento individual do preso. Além da delegacia e da penitenciária, existem também as modalidades de reclusão que chamamos de prisões-albergues que abrigam presos em regime semiaberto, nas quais os presos saem para trabalhar de dia e ali retornam para dormir. Ou ainda o livramento condicional, às vezes em forma de prisão domiciliar. ${ }^{15}$

Esse panorama nos ajuda a compreender a lógica e o contexto próprios da emergência prisional no Grão-Pará entre 1830 e 1845, no âmbito da Cabanagem. Ainda que o tema que propomos tratar neste artigo fuja ao contexto do processo de emancipação política do Brasil, o debate sobre o referido período faz-se mister para que se possamos melhor visualizar as dinâmicas sociais desencadeadas a partir deste momento no Grão-Pará, por tratar-se de um século onde o Império Brasílico encontrava-se em período de afirmação, sendo assim, Independência e Código Criminal do Império são temas que não podem ser analisados de maneira desconexa.

Para Sidney Chalhoub ${ }^{16}$ a independência obtida em 1822 implicava o desafio de construir o Estado nacional, isso queria dizer que era necessário organizar uma gama de questões e assuntos que competiam aos Poderes constituídos, que segundo Chalhoub tateavam no escuro em um "estado de desordem". 
No que se referia a necessidade de reformas na justiça penal do Estado, Flávio Albuquerque Neto $^{17}$, destaca que o debate ganha importância após o processo de emancipação política em 1822, resultando em 1830 no primeiro Código Criminal do Império, documento que passa a nortear as políticas de punição no Império Brasileiro em oposição ao "Livro V das Ordenações Filipinas”, determinações legais lusas que regiam as punições no Brasil durante quase todo o período Colonial. Para o autor as Ordenações Filipinas apresentavam em sua estrutura uma "confusão entre moral, religião e direito", além de um caráter violento. Segundo Neto:

(...) elas eram redistributivas, uma "retaliação do monarca" a algum abalo na ordem e um exemplo a ser tomado pelos demais. Por isso, a pena deveria ser afirmativa e exemplar; era um exercício de poder que deveria fazer-se inexorável e suscitar terror. Não é por outra razão que as punições no Antigo Regime eram um cruel espetáculo, um artifício pedagógico capaz de atingir o corpo do criminoso e impressionar os sentidos dos demais súditos e vassalos. ${ }^{18}$

Tal análise nos leva a refletir sobre as considerações estabelecidas por Michel Foucault, quando desenvolve a ideia de suplício, onde a pena era proporcional à desobediência da ordem cometida pelo condenado, demonstrando que esta categoria de punição não estava assentada no discurso de reinserção do apenado à sociedade, na verdade respondia a lógica de retaliação ao mal cometido.

O suplício penal não corresponde a qualquer punição corporal: é uma produção diferenciada de sofrimentos, um ritual organizado para a marcação das vítimas e a manifestação do poder que pune: não é absolutamente a exasperação de uma justiça que, esquecendo seus princípios, perdesse todo o controle. Nos "excessos" dos suplícios, se investe toda a economia do poder. ${ }^{19}$

Nesse sentido, o movimento de independência e o primeiro Código Criminal do Império da década de 1830 apresentavam características liberais e constitucionalistas, servindo tanto para por em desuso as leis da antiga metrópole, quanto para colocar em prática maneiras de punir definidas pelo Brasil enquanto Estado independente, buscando tornar mais próximas as normas de controle social da realidade brasileira quando da época de sua elaboração, sendo que neste novo aparato jurídico e penal, a prisão passa a ser a pena por excelência ${ }^{20}$.

Neste Código Criminal do Império estavam previstos como punições: Prisões com trabalho; Multa; Prisão Simples; Suspensão de Emprego; Perda de Emprego; Galés; Desterro; Morte; Açoite; Banimento ${ }^{21}$. Sendo assim, o crime adquire um caráter correcional, sendo que perdia o cunho religioso e moral, passando a ser visto como um ente eminentemente jurídico, 
voltado à lógica de reabilitação do criminoso através do hábito do trabalho ${ }^{22}$, religião e orientação moral. Diante disso:

A presença de pena com trabalho e o artigo 49 do Código Criminal, que afirmava a necessidade de casas correcionais onde esta pena pudesse ser aplicada com eficácia e presteza, impulsionou uma reforma penitenciária, em todo o Império a partir da década de 1830. Assim, em 1850 o Rio de Janeiro inaugurou sua casa de correção; São Paulo em 1852; em 1855, Pernambuco e a província de São Pedro do Rio Grande do Sul, entre outras. ${ }^{23}$

Diante do exposto, pretendemos nesse artigo discutir os reflexos deste Código Criminal e sua aplicação na província do Grão-Pará, abordando questões atinentes às prisões na referida província no contexto da Revolução Cabana, analisando as medidas executadas pelas autoridades provinciais voltadas para políticas de coerção e encarceramento, tais como a instalação da Cadeia São José em 1843. Para tal, serão utilizadas como fontes documentos oficiais e as notícias do periódico Treze de maio, num período que corresponde ao intervalo de tempo entre os anos de 1830 a 1845.

\section{O Código Criminal no Pará}

Quando entra em vigor o Código Criminal de 1830 percebe-se que é notória a necessidade das autoridades políticas locais em demonstrar à sede do Império que reinava a ordem e a paz no Grão-Pará. Tal argumento ganha força quando analisada a documentação referente aos Relatórios e falas dos Presidentes da Província do Grão-Pará entre as décadas de 1833 e 1850.

No relatório de 03 de dezembro de 1833, direcionado a junta regencial, época em que Machado D’Oliveira ocupava o cargo de Presidente da Província do Grão-Pará, já em sua segunda página afirma-se que:

[...] ella (A Província do Grão-Pará) desfruta sucego e segurança, como há muito não gozava, depois que a reflexão e a humanidade reassumiram o seu logar sobre o primeiro ímpeto do ressentimento que em quazi todos os Districtos causou a noticia do sanguinário acommettimento da facção restauradora, havido na capital em 16 de Abril deste anno e de que fostes testemunha. ${ }^{24}$

O referido acontecimento é ainda resultado das disputas e descontentamentos políticos oriundos do rumo que a província tomou quando da Independência. Nesse sentido, este contexto apresenta-se como um período onde havia a necessidade de afirmação do poder 
Imperial, bem como o provincial, no caso do Grão-Pará. O presidente da província continua o texto afirmando que:

\begin{abstract}
A nacionalidade tão cruelmente ofendida; a independência, o systema liberal tão de perto ameaçados; e o sangue Brasileiro atrozmente derramado por esses homens odiosos, e desde muito voltados à indignação pública, produsiram huma reação desmesurada: e actos de ferocidade, sub-equentes à agressão dos restauradores praticaram-se em alguns Distritos; aonde chegaram as primeiras notícias daquele acontecimento tão horrivelmente desfigurado. ${ }^{25}$
\end{abstract}

Neste ponto o relatório é bastante claro ao associar este "sanguinário acometimento da facção restauradora" como sendo uma ofensa à nacionalidade, sistema liberal e a independência. Tal discurso deve ser contestado por atribuir a independência e a adesão do Pará um caráter de disputas que tem como principal característica o patriotismo, sendo que no século XIX a nacionalidade brasileira estava sendo forjada e no Grão-Pará não seria diferente.

Ainda no Relatório de 1833, menciona-se sobre uma expedição que cometeu violências e arbitrariedades no dia 16 de abril de 1831 em uma vila localizada na Comarca do Rio Negro, território que, compunha a província paraense, posteriormente viria a se torna a província do Amazonas. Neste momento o Presidente da Província fala dos problemas e dificuldades que teve para intervenção no local, haja vista a distância e a ampla área composta por comarcas e freguesias a qual compunham a província.

As providencias compatíveis com os acanhados recursos à minha disposições, e com a tão grande distancia, em que se acha aquella vila, foram dadas para assegural-a de novo acommettimento, e para o procedimento jurídico, quer contra os fautores da desordem, como a cerca do fundamento. ${ }^{26}$

O Código do Processo Criminal representava no contexto de sua publicação uma das medidas tomadas pelas autoridades imperiais para a afirmação do Brasil como um estado independente, que formulou sua estrutura penal em oposição às normas estabelecidas pela antiga metrópole portuguesa. Nesse sentido era de vital importância para o governo provincial relatar a junta regencial o devido cumprimento dos termos pelo Código Criminal então definido, fator que fica claro quando o Sr. Machado D'Oliveira relata que

A nova divisão judiciária de Comarcas e Termos que sugerio o Código do Processo Criminal, foi pontualmente executada, e da maneira que vereis do Impresso apenço. Ahí se observa que foram criadas quatro Villas, cujas circunstâncias de localidade e população exigiam essa categoria, o que outras muitas perderão esse predicamentos por os motivos ponderados na Falla com que abri a Sessão deste Consellho em $1832 .^{27}$ 
A autoridade provincial dá continuidade ao discurso falando sobre a reação popular a respeito da aplicação dos termos estabelecidos pelo Código Criminal na província do GrãoPará no que diz respeito à divisão territorial.

Este procedimento que ferio antigos prejuízos de huns, caprichos de outros, em geral descontentou as respectivas populações, que não quizeram encarar essa medida como indispensável, atenta a diminuição que ellas tem sofrido a mingoa de instrução, e a falência de Cidadãos para os Cargos Públicos, que se argumentaram com o Código do Processo, tem sido sustentado pelo Governo em Conselho, que meditou profundamente sobre tão sisuda matéria, e só resolveu em presença de factos, de informações verídicas, e de próprios conhecimentos. ${ }^{28}$

O que se percebe então é que com a aplicação das normas estabelecidas no Código Criminal em parte da província do Grão-Pará, veio o descontentamento da população, fator que demonstra a dificuldade de aplicação desta nova estrutura penal na referida província.

O Código Criminal vai tendo lenta e defeituosa execução, pela multiplicidade de tropêcos, que se tem deparado e que são inevitáveis em similhantes transições rápidas: pelas grandes distancias que há a percorrer da Capital às diferentes Villas e Freguezias disseminadas pela extensíssima superfície da Província, e sem o socorro dos correios terrestres, que não podem ser admitidos pelos embaraços topográficos bem sabidos; e finamente por que o mesmo Código he susceptível de variadas interpretações e antinomias, he obscuro em algumas de suas partes, e pouco adaptado a compreensão vulgar. ${ }^{29}$

Para o Sr. Machado D’Oliveira a "extensíssima superfície da Província”, tornava trabalhosa a aplicação do Código Criminal, sendo que durante a década de 1830 no Grão-Pará não houve reformas ou construções de cadeias. Esse contexto foi marcado pela eclosão do movimento cabano em Belém sendo que o contexto que o sucede é marcado pelo empenho das "forças da legalidade" na desconstrução da memória do movimento em conjunto com uma série de medidas voltadas para a coerção e controle social.

\section{A Cabanagem no Grão-Pará.}

A eclosão da Revolução Cabana em 07 de janeiro de 1835 daria inicio a um período de insubordinações e luta que se espalharia por toda a extensão da Província do Grão-Pará e ultrapassaria suas fronteiras. Segundo Magda Ricci ${ }^{30}$ "A revolução social dos cabanos que explodiu em Belém do Pará, em 1835, deixou mais de 30 mil mortos e uma população local que só voltou acrescer significativamente em 1860". Luta essa que representada pelo 
segmento social pobre da cabanagem estava assentada no "ódio ao mandonismo branco e português e na luta por direitos e liberdade" 31 .

Apresentando um esboço do pensamento político-revolucionário paraense no século XIX, Vicente Sales ${ }^{32}$ procura analisar a cabanagem como um processo contínuo entendendo-o como uma revolução. Segundo o autor o pensamento político burguês europeu reverberou no Grão-Pará ainda na primeira metade do século XIX, e se materializou com a criação de Clubes e demais organizações de caráter abolicionista e republicano ${ }^{33}$.

Vicente Sales ressalta que a vizinhança do Grão-Pará com a Guiana Francesa foi um fator que possibilitou a chegada de ideais de igualdade a província brasileira, difundidos entre as classes menos favorecidas economicamente, notadamente entre os escravos. Os ecos da Revolução Francesa teriam alcançado a diversas regiões do mundo e segundo o autor "Por mais distante que fosse esta parte da colônia lusitana na América, não podia deixar de perceber o que acontecia no mundo. O tráfico de ideias se fazia, portanto, intensamente." ${ }^{34}$

Tais ideais segundo Sales foram de suma importância para o movimento cabano, indicando uma consciência de classe que viria a se formar. A ideia de "classe" faz referência não a classe trabalhadora da maneira que a historiografia marxista inglesa tradicionalmente analisa o movimento operário, mas sim a uma lógica específica que se deve ao fato de que diferentemente da Europa, a sociedade brasileira no século XIX viveu a realidade da escravidão, fator que segundo Vicente Sales impediu a organização de trabalhadores em sindicatos.

Magda Ricci aborda a ideia de patriotismo dentro do movimento cabano. Ressalta que patriotismo e nacionalismo são conceitos diferentes e não se confundem em sua análise. Esse patriotismo cabano teria relação com o sentimento de identidade que se desenvolve no interior da Amazônia entre negros, índios, mestiços que a apesar de possuírem etnias e origens diferentes, compartilhavam de problemas em comum ${ }^{35}$.

Neste sentido, Magda Ricci $^{36}$ argumenta que durante o processo revolucionário surge uma experiência de classe entre os cabanos e seus líderes, no decorrer da eclosão cabana em sete de janeiro de 1835 e agosto deste mesmo ano. Neste contexto, Felix Clemente Malcher, presidente "aclamado" ao governo pelo povo, depois de sucessivas atitudes que causaram descontentamento tanto para seus partidários principais: Eduardo Angelim e Francisco Vinagre, quanto para a massa cabana.

Ainda que tentando frear o ímpeto revolucionário cabano no momento posterior a tomada da capital do Pará, Félix Clemente Malcher e seus compatriotas cabanos redigiram um 
documento no qual atribuem a morte do antigo presidente Bernardo Lobo de Sousa às suas atitudes cheias de prepotência e arbitrariedades, que causaram exaustão generalizada à população. Neste documento Malcher e os que o assinaram, solicitavam a Regência que não houvesse nomeação para o lugar de Lobo de Sousa até que Dom Pedro II alcançasse a maioridade, pois eles não aceitariam “qualquer presidente que a Regência lhes mandasse" ${ }^{{ }^{37}}$.

Abre-se espaço para que esta massa comece a eleger líderes e ampliar a luta, saindo de Belém nos anos subseqüentes e espalhando-se por vasta região do território amazônico, revelando que a luta representada pelo segmento social pobre da cabanagem estava assentada segundo Magda Ricci no ódio ao mandonismo branco e português e na luta por direitos e liberdade, nesse sentido o conceito de patriotismo distancia-se ainda mais de nacionalismo. Para Magda Ricci ${ }^{38}$ :

O que quero ressaltar é que o movimento cabano foi complexo. Ao lado da luta de classes e da formação do império, há uma árdua batalha identitária, que demorou mais de um século para se consolidar. Na década de 1830, entretanto, essa batalha tinha matizes mais liberais e abrangentes, que nem sempre incluíam a junção do Grão-Pará à corte carioca. Da elite de Belém e arredores ao povo das vilas interioranas, dos problemas mais macro do regime político e econômico do GrãoPará aos levantes das tropas e da escravaria, toda a população amazônica e sua diversidade também não eram insignificantes.

O que se percebe diante destas considerações é que durante o momento em que a cidade de Belém encontrava-se tomada pelo governo cabano, os mandos regenciais não seriam obedecidos, posto que estes não viam na Regência uma autoridade política legítima, a autoridade para eles estava agora por ser forjada dentro do processo revolucionário.

Nessa perspectiva, os conflitos armados e a luta de cabanos contra autoridades, militares e mesmo as lutas internas, resultaram na destruição de boa parte do espaço físico da cidade de Belém, fazendo necessárias medidas de reestruturação do espaço urbano da capital do Grão-Pará, visando sua recuperação e "pacificação". Construções de igrejas, prédios, cemitérios, mudanças em nomes de ruas, foram algumas das medidas desencadeadas pelas autoridades imperiais associadas a uma tendência de desarticulação da memória recente da Cabanagem que em nada ou muito pouco era benéfica a elite política paraense nesse contexto. Para Eliana Ramos Ferreira ${ }^{39}$ :

(...) A recuperação física da cidade tornou-se uma das prioridades do governo. Recursos foram alocados "para melhoramento e aformoseamento das estradas". Obras públicas, como a edificação e conserto das igrejas, da cadeia pública, construção de um novo prédio para abrigar a "Casa do Ver-o-Pezo", limpeza de valas, plantio de árvores e manutenção de um Horto Botânico, entre outras obras, são implementadas refletindo a ação conjunta do governo e da Câmara Municipal no 
sentido de higienizar a cidade da presença dos cabanos, apagando os vestígios de sua permanência na cidade e no governo - além do soerguimento físico, era necessário construir uma memória sob a ótica do vencedor.

\section{Prisão e Trabalho: instrumento de coerção e controle social}

Magda $\operatorname{Ricci}^{40}$ apresenta importantes considerações atinentes à situação das prisões no Grão-Pará na década de 1830, afirmando que na região Amazônica tais espaços não se constituíam em "ambientes de exclusão social para pagamento de dívidas e de infrações", mas sim um lugar de espera do castigo, sendo que tais ambientes poderiam ser: cadeias, prisões, aljubes, fortalezas e navios, e podiam servir para mulheres, militares, livres e escravos ${ }^{41} . \mathrm{Na}$ maioria das vezes os presos arcavam com as próprias despesas dentro do cárcere, fator que causava preocupações nos presidentes da província, que frequentemente solicitavam recursos à corte para manter os presos pobres ${ }^{42}$.

A existência de diversas formas de cárcere nos sugere que as formas de punir eram variadas e nos permitem elaborar indagações ao seu respeito, tais como: em que se baseava o princípio de punição no Grão-Pará em tempos de cabanagem? Pretendemos demonstrar argumentos que nos permitam visualizar melhor essa indagação ao longo do texto.

Segundo Ricci $^{43}$ as cadeias públicas situavam-se geralmente num mesmo prédio que Casas de Câmara de Vereança e havia ou deveria haver selas separadas ${ }^{44}$, para livres, escravos, homens e mulheres como determinava a Constituição de 1824 que segundo Oliveira ${ }^{45}$ e Neto ${ }^{46}$ exigia que nas prisões fosse respeitado o princípio da separação dos presos por sexo, gravidade de seus crimes e condição social, determinação que muito frequentemente não era respeitada em função de problemas como: superlotação e precariedade dos edifícios.

Neste contexto instituem-se na província do Grão-Pará os Corpos de Trabalhadores de 1838 , instrumento de coerção ao trabalho de "índios, mestiços e pretos não escravos" e sem propriedades ou ocupações reconhecidas como constantes ${ }^{47}$ foi uma das medidas de repressão ao movimento cabano, tinha como objetivo combater "homens ociosos e vagabundos" espalhados pela província.

A partir de 1840 iniciam-se uma década onde a preocupação com a ordem se torna prioridade da política imperial. Segundo Ilmar Rohloff de Matos, a lógica econômica que vem a se definir no império brasileiro divide-se em três mundos: o mundo do governo (elite imperial, e demais componente da "boa sociedade"), mundo do trabalho (escravos) e mundo da desordem, sendo que este último se tratava de segmentos sociais que não se identificavam em nenhuma das duas primeiras lógicas ${ }^{48}$. 
Nota-se então que as "forças da legalidade" empenham-se na desconstrução da memória do movimento em conjunto com uma série de medidas voltadas para a coerção e controle social, caracterizando uma visão de sociedade marcada por um binarismo pautado em um mundo da ordem e o outro da desordem, bem como um da Lei e um do Crime, além do lançamento do Jornal Treze de Maio, o periódico da "legalidade"49 que afirmava em sua edição de 13/05/1840 que o ano de 1840 representa um período de "retomada da paz" da capital da província do Grão-Pará pelas forças da "legalidade e da ordem", tendo passado meia década de luta em diversas partes da província provenientes do movimento da Cabanagem (1835-1839), muito embora a historiografia tenha demonstrado que esse período se estendeu para além da década de $1840^{50}$ nas demais partes da província.

A partir da década de 1840 a preocupação com cadeias para as regiões mais afastadas da capital Belém é notória nos discursos e relatórios provinciais, além das solicitações de reformas na cadeia pública da Capital e das cadeias pelo Império. Em 1840 João Antônio de Miranda ocupava o cargo de presidente da província do Grão-Pará. Em discurso dirigido à Corte a autoridade provincial afirma que:

As casas de Câmaras, Cadeias, e Matrizes, são as primeiras obras, ou edifícios públicos de uma Villa. Além de um goso, ou satisfação de uma necessidade, que se procura, deve também encontrar-se o desempenho dos preceitos da arte, e a perfeição necessária, para que nem deixem de ornar os respectivos municípios, nem tornem pesaroso o observador, nem causem finalmente arrependimento à sociedade, que as fez construir ${ }^{51}$.

A lógica de reestruturação da província no discurso de João Antônio de Miranda, esta assentada num tripé igreja-casa de vereança-cadeia, como exposto na continuação de sua fala sobre as Vilas da Comarca do Baixo Amazonas:

Tapajóz necessita reparar sua Igreja Matriz: ela foi erecta com esmolas dos fieis, porém hoje suas contribuições não podem chegar para os indispensáveis concertos. Essa imporane Villa exige uma Casa de Câmara e uma cadeia ${ }^{52}$.

Sobre a Vila de Macapá, assim como o Tapajóz, localizada no Baixo Amazonas relatase que:

O magnífico edifício da Cadeia da Villa de Macapá ameaça total queda. (...) A caridade dos fies Macapoáras não pode já aprarar a deteriorada Matriz do município. (...) A Câmara é pobre: nem mesmo aos seus empregados pode pagar ${ }^{53}$.

Ainda sobre a região do Baixo Amazonas, relata-se que: 
Matriz, Casa da Câmara, e Cadeia não em a Villa de Monte Alegre. A boa disposição de seos habitantes pode concorrer muito, para que se edifique um Templo; mas um socorro de doutros contos de réis será sem dúvida necessário ${ }^{54}$.

Por fim, o discurso demonstra de maneira mais específica as razões da necessidade de construção de cadeias nas áreas do Baixo Amazonas quando afirma que:

A Villa do Gurupá, pela sua localidade, pode vir a tornar-se mui importante, e é preciso não desprezar os elementos, que podem apressar a sua prosperidade. A única prisão, que nessa Villa existe, é a militar, mas essa mesma é pequena, e não possui a segurança indispensável. Não há nas Freguesias, e lugares, que compõem o termo, um só cuja igreja não precise de reparos. O centro da Villa necessita de um caes para embarque e desembarque ${ }^{55}$

Como demonstrado pelo discurso de João Antônio de Miranda, as cadeias compunham um conjunto de necessidades institucionais, assim como as casas de vereança ou de câmaras juntamente com igrejas, e serviam também para demonstrar à população a presença do Estado nas vilas, não é à toa que as cadeias eram construídas junto às casas de Câmaras e rotineiramente nos centros da cidade.

A solicitação de construção de Cadeias na Região do Baixo Amazonas sugere responder a necessidade de um aparato militar presente na referida região, em função de ser uma área de fronteira com a Guiana, e por isso ser mais vulnerável a possíveis invasões estrangeiras, bem como insubordinações locais, mas estava associada também a uma nova maneira de lidar com as questões criminais no Brasil e no mundo, sendo assim, as cadeias representavam a modernidade para resolver questões urbanas, ainda que na realidade as condições dos presos fossem precárias.

Àquela época, a cadeia pública da capital paraense localizava-se na Rua dos Mercadores, como relata o missionário metodista americano Daniel Parish Kidder (18151891), que durante suas viagens pela região norte do Império Brasileiro anotara que:

A cadeia (...) tem a data de 1775 , E' bem edificada e, no segundo andar, está instalada a Câmara Municipal. Através das grades os presos exibem brinquedos e bugigangas que fabricam para vender, e, estando a prisão situada - como em quase todas as cidades brasileiras - em ponto central do lugar, é provável que consigam dispor de grande parte dos artigos que produzem ${ }^{56}$.

Analisando a documentação referente ao periódico Treze de Maio, a primeira menção à referida cadeia encontrada faz referencia a um anuncio de Izidoro Ferreira da Costa, que necessitava contratar um "caxeiro que entenda de escripturação" e que sua casa se localiza na rua da cadeia ${ }^{57}$. A partir deste anúncio e nos anos subsequentes percebe-se que são muitos os anúncios que se referem ao prédio como "cadeia" ou "cadeia desta cidade" 58 sempre 
utilizando a cadeia como ponto e referencia aos moradores dos arredores, como em anúncios de fuga de escravos ${ }^{59}$.

Percebe-se que a cadeia servia de referência em termos de localização aos moradores. A rua na qual foi instalada chamava-se Rua dos Mercadores, entretanto, com o tempo, a referencia a rua passou a ser Rua da Cadeia, ao ponto de nos do Jornal Treze de Maio a denominação anterior com o tempo ter sido substituída pela Rua da Cadeia ${ }^{60}$.

O nome da rua da CADEIA proveio do fato de ser situado o presídio da capital nos baixos da Casa da Câmara. As exigências arquitetônicas da época modificaram a frontaria dos $\operatorname{Paços}^{61}$.

Realizando viagens pelos rios Amazonas e Rio Negro, entre os anos de 1848 e 1852, o a naturalista, geógrafo, antropólogo e biólogo britânico Alfred Russel Wallace (1823-1913), fez muitos relatos de suas impressões sobre as Províncias do Norte do Brasil. Dentre estes relatos, existe um no qual fala sobre a Rua dos Mercadores, afirmando que:

A "Rua dos Mercadores", que é a via principal, concentra quase todas as boas lojas da cidade. As casas de moradia, em sua maior parte, só tem um pavimento, mas as lojas, em geral completamente abertas na frente, apresentam-se limpas e atrativamente sortidas, se bem que o conjunto de seus artigos forme uma verdadeira miscelânea. Nessa rua existem alguns trechos calçados, de umas poucas jardas de extensão, tão pequenos que servem apenas para tornar comparativamente mais desagradável o resto da caminhada sobre pedras irregulares ou areia fofa. ${ }^{62}$

Percebemos, então, que as Ruas dos Mercadores, bem como a Cadeia Pública, localizavam-se em um ponto central da cidade, possivelmente habitado por comerciantes e vendedores em suas redondezas. Havia, também, edifícios pertencentes ao poder público, tais como o Palácio do Governo e outros tipos de cárcere, como aljubes. A instalação da Cadeia no centro da cidade sugere corresponder à necessidade de vigilância bem como uma tentativa de desarticular possíveis fugas de presos em áreas mais afastadas do centro, como matas ou rios, pois tais espaços poderiam ser mais propícios a sua dispersão.

Não obstante a solicitação do presidente João Antônio de Miranda para com o "desempenho dos preceitos da arte, e a perfeição necessária" as cadeias no Império Brasileiro e no Grão-Pará encontravam-se em uma realidade bem diferente. Apresentavam condições precárias em termos de estrutura e administração, fator que é demonstrado pelas frequentes queixas dos presidentes da província a respeito das cadeias.

Em discurso de 1841, quando aborda a administração da justiça, o presidente Bernardo de Souza Franco menciona que existe a necessidade da construção de cadeias bem estruturadas e de melhorias das que já existiam, sugerindo que para resolver esses problemas 
fosse destinado uma determinada quantia anual para que se possa reformar/construir cadeias seguras:

Há ainda uma necessidade urgente a satisfazer, e que diz respeito a esse ramo de serviço público, e há factura de Cadêas seguras, e arejadas, ou o concerto das que actualmente existem e exigem reparos ${ }^{63}$.

Nesse contexto no o Código Criminal passa por um processo de reformulação, através da Lei $\mathrm{N}^{\circ} 261$ de 3 de dezembro de 1841, logo após Dom Pedro II assumir o trono, num momento que representa o avanço conservador na política imperial, a Lei reduziu a liberdade do ordenamento processual ao subtrair dos juízes de paz as atribuições de investigar para entregá-las a Polícia e delegados. Como demonstrado no Artigo $6^{\circ}$ da Lei, da primeira disposição da referida Lei

As attribuições criminaes e policiaes que actualmente pertencem aos Juizes de Paz, e que por esta Lei não forem especialmente devolvidas ás Autoridades, que crêa, ficão pertencendo aos Delegados e Subdelagados. ${ }^{64}$

A reforma de 1841 representa, portanto, um momento marcado pela intervenção saquarema na política imperial, fortalecendo o aparato repressivo do Estado em uma época de crise política e social agravada por diversas rebeliões que agitaram o império desde a abdicação do primeiro Imperador em 1831. Para resolver tais demandas, a solução tomada pelas autoridades oficiais foram ações de caráter reacionário e centralizador no âmbito da justiça penal.

A relação entre esta política centralizadora e o advento das cadeias no império diz respeito a uma maneira tida como moderna para a resolução de problemas criminais, fazendo com que prisões quarteis, fortalezas, dentre outras formas de encarceramento, especificamente e de punição, de maneira geral, características do período colonial fossem paulatinamente substituídas por cadeias ${ }^{65}$.

Em 1842 Bernardo de Souza Franco solicita "concerto de algumas Cazas de Camara, e cadêas" , e no ano seguinte o então presidente da província Snr. Coronel Jozé Thomaz Henriques relata que

A cadeia desta cidade está a desabar: o seu desmoronamento é inevitável; pelo que vou ordenar que se mudem os presos para outra qualquer parte, para evitar que fiquem sepultados debaixo das ruínas d'aquelle vacilante edifício: vós comprehendereis, de quanta necessidade não é cuidar imediatamente de nova Cadêa, para se principiar a qual é indispensável, voteis alguma quantia, que até que vos sejaõ presentes a Planta, e o orçamento de tal obra; e por esta ocasião, senhores, desmandarei taõbem maior quota para os prezos pobres, pois que não fosse a de $300 \$ 000$ réis, que lhes votastes para luz, e agoa no Art. $2 .^{\circ}$ da Lei N. ${ }^{\circ} 109$ de 6 de dezembro de 1841 , eles terião sofrido os rigores da fome do ultimo Junho em diante, 
em que findou o orçamento das Rendas Geraes, por quem erão alimentados; e desde quando não tiveraõ mais suprimentos pela Caixa Geral. ${ }^{67}$

O referido discurso nos permite visualizar as condições precárias que a Cadeia Pública se encontrara no início da década de 1840, o risco de desabamento, fome, falta de vestimenta, além das doenças e epidemias de cólera, febre amarela e que assolaram a cidade de Belém durante o século $\mathrm{XIX}^{68}$ eram a realidade dos presos desta cadeia.

Diante da situação da Cadeia Pública de Belém, após exame e vistoria realizada por peritos a mando da Câmara Municipal da Cidade de Belém deste prédio que também servia de Casa da Câmara, os presos que lá se encontravam encarcerados foram transferidos no ano de 1843 para o edifício que viria a funcionar como Cadeia até fins da década de 90 do século XX. Trata-se do contexto de instalação da Cadeia São José.

Devo finalmente informar-vos sobre este objeto que os presos que se achavam na antiga e arruinada Cadêa, forão transferidos para o edifício de S. José em que se fizerão alguns reparos para segurança e comodidade dos mesmos presos ${ }^{69}$.

No Pará a prisão representou um importante mecanismo de controle social num momento no qual a memória recente da Cabanagem fez surgir na "boa sociedade" o medo de uma revolta de escravos ou "novas Cabanagens". Neste sentido, para considerar que o período de "emergência prisional" no Pará esteve ligado a novas estratégias de governo voltadas a repressão aos cabanos é preciso levar em consideração que a população livre e pobre, composta por seja por brancos ou negros, passa também a ser alvo desta política de controle social. Nessa perspectiva, é importante ressaltar que no Império Brasileiro as punições não se davam da mesma maneira para escravos e cidadãos livres. Como afirma Flávio de Albuquerque Neto:

(...) a população livre, fosse ela branca ou negra, também seria alvo dos mecanismos de controle social, incluindo neles a prisão. Contudo a esses presos "comuns" destinava-se um modelo de prisão penitenciária ressocializante, consectário do projeto liberal emergente, enquanto à população escrava, que era tida como incorrigível, devendo ser levada à prisão apenas para ser açoitada ou custodiada enquanto cumpria a pena de galés (artigo 60), a funcionalidade do sistema prisional deixa de ter um cunho preventivo e correcional e passa a ser meramente punitivo retributivo $^{70}$.

Quando analisada a documentação do Arquivo Público do Estado do Pará referente à Relação nominal dos rebeldes presos, ou seja, os indivíduos envolvidos com o movimento cabano, entre os anos de 1835 e 1836, percebe-se que o destino dos presos cabanos não era as cadeias públicas localizadas nas áreas urbanas da cidade. Para os cabanos recolhidos pelas 
forças da legalidade o destino mais frequente era a Corveta Defensora, além da prática do desterro e da ação dos Corpos de Trabalhadores.

\section{Considerações finais.}

Apesar do empenho e do investimento da política provincial em medidas de segurança pública em consonância com o Código Criminal que entra em vigor no Império Brasileiro na década de 1830, sua aplicação no Grão-Pará foi lenta e ineficiente. Tal argumento não se demonstra unicamente pelas frequentes reclamações dos presidentes das províncias em seus relatórios anuais sobre termos estabelecidos no referido Código, mas também a eclosão do movimento cabano em Belém e nas demais partes da província do Grão-Pará em 1835, com sua continuação nos anos subsequentes, não via na Regência a autoridade política legítima.

A presença de variados tipos de ambientes de cárcere na década de 1830 (aljubes, fortalezas, cadeias públicas, etc.) demonstra que eram muitas as formas de punir, sendo que os princípios que norteavam o grau de punição eram dois: condição social e envolvimento com a cabanagem. A partir da década de 1840 ocorre uma medida centralização dos instrumentos de encarceramento (cadeias) ligada com a política saquarema e resultado dos debates sobre reformas prisionais que fazem parte de um projeto civilizatório datado do século XIX, acontecidos na Europa e Estados Unidos.

Nesse sentido, consideramos que a necessidade de reforma e construções de cadeias em Belém e nas demais cidades da província paraense, bem como a necessidade de estratégias de criação de instituições de caráter repressivo relacionam-se com o contexto da administração saquarema que representa o avanço conservador na política imperial e teve intrínseca relação com o movimento cabano na medida em que se espalhava pelos interiores e áreas de fronteiras com outras províncias e países.

Ainda que as cadeias não tivessem sido o destino dos cabanos em Belém, eram ambientes destinados às classes pobres e correspondiam as necessidades institucionais voltadas à manutenção da ordem, nos fazendo pensar que as prisões no Pará, bem como o hábito do trabalho como coerção, desempenhavam um papel essencial no funcionamento da sociedade naquele contexto, pois os indivíduos que fossem um obstáculo à economia (escravista) do Pará no século XIX passam a ser o alvo deste tipo de exílio, baseado na segregação das sociedades "problemáticas". 


\section{Notas}

${ }^{1}$ OLIVEIRA, Fernanda Amaral. Os modelos penitenciários no século XIX. Seminário Nacional de História da Historiografia: historiografia brasileira e modernidade, ocorrido na cidade de Mariana MG entre os dias 01 a 03 de agosto de 2007. Disponível em: 〈http://www.ufjf.br/virtu/files/2010/05/artigo-6-a-1.pdf>

${ }^{2}$ ELIAS, Norbert. O Processo civilizador (Vol.01): uma história dos costumes. Rio de Janeiro: Zahar, 2011.

${ }^{3}$ ELIAS, 2011, p. 185

${ }^{4}$ CHIAVERINI, Tatiana. Origem da pena de prisão. Dissertação (Mestrado em Filosofia do Direito). Pontifícia Universidade Católica, São Paulo: 2009.

${ }^{5}$ CHIAVERINI, 2009, p. 19.

${ }^{6}$ BITTENCOURT, Cezar Roberto. Falência da Pena de Prisão: causas e alternativas. São Paulo: Ed. Saraiva, 2001.

${ }^{7}$ GINZBURG, Carlo. Medo, reverência e terror. São Paulo: Cia das Letras, 2014.

${ }^{8}$ GINZBURG, 2014, p. 16.

${ }^{9}$ Idem, p. 26

${ }^{10}$ BITENCOURT, Op. Cit. p.07

${ }^{11}$ FOUCAULT, Michel. Vigiar e Punir. $40^{\circ}$ Ed. Petrópolis - RJ: Vozes, 2012, p. 13.

${ }^{12}$ SÁ, Geraldo Ribeiro de. A prisão dos excluídos: origens e reflexões sobre a pena privativa de liberdade. Juiz de Fora: UFJF, 1996.

${ }^{13}$ REGO, Isabel Pojo. Sociologia da prisão. Soc. estado. vol.19 no.1 Brasília Jan./June 2004. Disponível em: $<$ http://www.scielo.br/scielo.php?script=sci_arttext\&pid=S0102-69922004000100011 >. Acesso em: 25/05/2016.

${ }^{14}$ No caso paraense durante o processo de adesão do Pará a Independência em 1823 e seus respectivos desdobramentos, José Alves Junior (2013), destaca que a perseguição política àqueles que resistiram a adesão em uma clara manifestação de lusofobismo culminou em uma noite de intensos distúrbios entre os dias 15 e 16 de outubro de 1823, denotando uma espécie de encarceramento por autoridade, seguida de um massacre em massa. Segundo Alves Junior "Alarmado com tais acontecimentos, Batista Campos solicitou a intervenção de Grenfell, que ordenou a prisão de todos os indivíduos encontrados nas ruas da cidade ou que tivessem sido denunciados como agitadores (tal ordem levou ao episódio do Brigue Palhaço, em que centenas de pessoas, que haviam sido presas por distúrbios, morreram afixadas no porão do referido navio). ” (ALVES JUNIOR, 2013, p. 36)

${ }^{15}$ REGO, Op. Cit. p. 230.

${ }^{16}$ CHALHOUB, Sidney. População e Sociedade. In: CARVALHO, José Murilo de. História do Brasil Nação: A construção nacional (1830-1889). Rio de Janeiro: Objetiva, 2012.

${ }^{17}$ NETO, Flávio de Sá Cavalcanti. A Reforma Prisional no Recife oitocentista: da cadeia à casa de detenção (1830 - 1874). Dissertação (mestrado) - Universidade Federal de Pernambuco. CFCH. História, 2008.

${ }^{18}$ NETO, Op. Cit. p. 28.

${ }^{19}$ FOUCAULT, Op. Cit. p.36.

${ }^{20}$ NETO, Op. Cit.

${ }^{21}$ Lei de 16 de dezembro de 1830. Título II: Das Penas - Capítulo I - Da qualidade das penas, das penas, e da maneira como he hão de impor, e cumprir. Disponível em: <http://www.planalto.gov.br/ccivil_03/leis/LIM/LIM-16-12-1830.htm>. Acesso em: 24/05/2016.

${ }^{22}$ As prisões com trabalho em suas duas variantes correspondiam a aproximadamente $53 \%$ das penalidades em todo o Império segundo a análise de Flávio de Sá de Albuquerque Neto (2008).

${ }^{23}$ NETO, Op. Cit. p. 47.

${ }^{24}$ PARÁ, Governo. Relatório do Presidente da província do Gram-Pará, o Exm. Sr. José Joaquim Machado D’Oliveira, no dia 3 de dezembro de 1833. Pará, Typ. Do Corrêa, 1833. P. 1.

${ }^{25}$ PARÁ, Op. Cit.

${ }^{26}$ PARÁ, Op. Cit. p. 2.

${ }^{27}$ PARÁ, Op. Cit., p. 2.

${ }^{28}$ PARÁ, Op. Cit.

${ }^{29}$ PARÁ, Op. Cit.

${ }^{30}$ RICCI, Magda. Cabanagem, cidadania e identidade revolucionária: o problema do patriotismo na Amazônia entre 1835 e 1840. Revista Tempo, v. 11, n. 22, p. 5-30, 2007, p. 06.

${ }^{31}$ RICCI, Op. Cit., 2007, p. 7.

${ }^{32}$ SALLES, Vicente. Memorial da Cabanagem: esboço do pensamento político-revolucionário no Grão-Pará. Edições CEJUP, 1992.

${ }^{33}$ Desde a eclosão do movimento cabano até os dias de hoje a historiografia e as visões atribuídas a cabanagem passam por uma série de mudanças. Na década de 1990 historiadores e estudiosos como Vicente Sales tenderam a analisar a cabanagem como uma revolução popular, ressaltando o seu pensamento político ideológico e 
contrariando a as análises que tendem a analisar a ação dos cabanos num vácuo político ou por incompetência dos governantes, como a afirmavam os primeiros escritos sobre cabanagem.

${ }^{34}$ SALLES, 1992, pp. 23-24.

${ }^{35}$ RICCI, Magda, 2007, Idem.

${ }^{36}$ RICCI, Magda. Cabanos, patriotismo e identidade: outras histórias de uma revolução. In: GRINBERG, Keila e SALLES, Ricardo. O Brasil Imperial, vol. II. Rio de Janeiro: Civilização Brasileira, 2011.

${ }^{37}$ RICCI, 2007, p. 13.

${ }^{38}$ RICCI, 2011, p. 221

${ }^{39}$ FERREIRA, Eliana Ramos. Cidade de Malvadezas ou de Matar "Bicudos"? Belém entre a Cabanagem e a Belle Époque. ANPUH - XXV Simpósio Nacional de História - Fortaleza, 2009, p. 02.

${ }^{40}$ RICCI, Magda. Um morto, muitas mortes: a imolação de Lobo de Souza e as narrativas da eclosão cabana. In: NEVES, Fernando Arthur de Freitas \& LIMA, Maria Roseane Pinto. Faces da História da Amazônia. Belém: Paka-Tatu, 2006, pp. 519-544.

${ }^{41}$ RICCI, 2006, p. 529.

${ }^{42}$ Os presos pobres eram aqueles que viviam à custa dos cofres provinciais, além de ter o sustento e vestimenta garantidos, não precisava pagar pelos selos em documentos oficiais que porventura viesse emitir, como por exemplo, uma petição de graça ao imperador, entre outros. Conferir em PARÁ, Governo. Índice ou repertório geral das leis da assembleia legislativa provincial do Gram Pará (1838-1853), por André Curcino Benjamim (Chefe de secção da thezouraria de fazenda da mesma província), 1854, p. 53.

${ }^{43}$ RICCI, 2006.

${ }^{44}$ Fernanda Amaral de Oliveira (2007) em artigo intitulado "Os modelos penitenciários no século XIX”, destaca que o sucesso das penitenciarias americanas da Filadélfia e Pensilvânia, foram replicados em Auburn no Alabama e na Irlanda, destacando o local das selas como espaço de recolhimento noturno, após regime de trabalho diurno sob controle e vigilância, ainda segundo Oliveira no caso da Irlanda surgiu um novo modelo que para ela pode ser considerado como um aperfeiçoamento dos dois modelos americanos a partir de 1853, onde o apenado percorre quatro fases entre a sua entrada e a conquista definitiva da liberdade.

${ }^{45}$ Idem.

${ }^{46}$ Idem.

${ }^{47}$ FULLER, Claudia Maria. Os Corpos de Trabalhadores e a organização do trabalho livro na província do Pará (1838-1859). Revista Mundos do Trabalho, vol. 3, n. 6, julho-dezembro de 2011. p. 52-66. P. 52.

48 MATOS, Ilmar Rohloff de. O Tempo saquarema: a formação do estado imperial. São Paulo: HUCITEC, 2004.

${ }^{49}$ RICCI, 2013, p. 71.

${ }^{50}$ RICCI, 2013, p. 51.

${ }^{51}$ PARÁ, Op. Cit., 1840, p. 93.

${ }^{52}$ PARÁ, Op. Cit., 1840, p. 107.

${ }^{53}$ PARÁ, Op. Cit., 1840, p. 108.

${ }^{54}$ PARÁ, Op. Cit., 1840, p. 111.

${ }^{55}$ PARÁ, Op. Cit., 1840.

${ }^{56}$ Conferir em KIDDER, Daniel P. Reminiscências de Viagens e Permanências no Brasil, Compreendendo Notícias Históricas e Geográficas do Império e das Diversas Províncias. São Paulo: Livraria Martins Editora; Editora da Universidade de São Paulo, 1972, p. 173.

${ }^{57}$ Treze de Maio, 22 de janeiro de 1845, p.3.

${ }^{58}$ Treze de Maio, 12 de fevereiro de 1845, p. 4.

${ }^{59}$ Treze de Maio, 15 de fevereiro de 1845 , p. 3.

${ }^{60}$ Treze de Maio, 5 de abril de 1845, p. 4.

${ }^{61}$ CRUZ, 1973, p. 191.

62 Conferir em WALLACE, Alfred Russel, 1823-1913. Viagens pelos Rios Amazonas e Negro. Tradução Eugenio Amado; apresentação Mário Guimarães Ferri. - Belo Horizonte: Ed. Itatiaia; São Paulo: Ed. da Universidade de São Paulo, 1979, p. 19.

${ }^{63}$ PARÁ, Governo. Discurso recitado pelo exm. Sr. Bernardo de Souza Franco, presidente da província do Gram-Pará, na abertura da Assembleia Legislativa Povincial no dia 14 de abril de 1841. Pará, Typ. de Santos \&. Menor, 1841, p. 22.

${ }^{64}$ Lei No 261, de 3 de Dezembro de 1841, art 6.

Disponível em: http://www.planalto.gov.br/ccivil_03/leis/LIM/LIM261.htm

${ }^{65}$ De acordo com Carlos Aguirre (2009) em "Cárcere e Sociedade na América Latina (1800-1940)" durante o período colonial no Brasil, as prisões aconteciam de forma esporádica e tinham entre outras funções a finalidade de recolher aqueles que eram suspeitos de crimes ou que aguardavam sentença. 


\footnotetext{
${ }^{66}$ PARÁ, Governo. Discurso recitado pelo exm. Sr. Bernardo de Souza Franco, vice-presidente da província do Gram-Pará, na abertura da Assembleia Legislativa Povincial no dia 15 de abril de 1842. Pará, Typ. de Santos \&. Menor, 1842 , p. 29

${ }^{67}$ PARÁ, Governo, Discurso recitado pelo exmo. Snr. Coronel Jozé Thomaz Henriques, presidente da Província do Pará, na abertura da segunda sessão da Assembleia Legislativa Provincial no dia 15 de agosto de 1843. Pará, typ. de Santos e Menores, 1843, p.13.

${ }^{68}$ Ver: BELTRÃO, Jane Felipe. Epidemia e sociedade: como fotografar o social via Cólera. In: Cólera: o flagelo da Belém do Grão-Pará. Belém: Museu Paraense Emilio Goeldi; Universidade Federal do Pará, 2004.

${ }^{69}$ PARÁ, Governo. Discurso recitado pelo exm. Sr. Desembargador Manuel Paranhas da Silva Vellozo, presidente da Província do Pará, na abertura da primeira sessão da quarta legislativa da Assemblea Provincial no dia 15 de agosto de 1844. Pará, typ. de Santos e Menores, 1844, p. 42.

${ }^{70}$ NETO, 2008, p. 52.
}

\section{Referências bibliográficas}

AGUIRRE, CARLOS. Cárcere e Sociedade na América Latina (1800-1940). In: MAIA, Clarisse, NETO, Flávio, COSTA, Marcos costa, BRETAS, Marcos (orgs.). História das prisões no Brasil. vol. 1. Rio de Janeiro: Rocco, 2009.

BITTENCOURT, Cezar Roberto. Falência da Pena de Prisão: causas e alternativas. São Paulo: Ed. Saraiva, 2001.

BRETAS, Marcos Luiz. A Polícia Carioca no Império. Revistas de estudos históricos, Rio de Janeiro, v, 12, n. 22, p. 219-234, 1998.

CHALHOUB, Sidney. População e Sociedade. In: CARVALHO, José Murilo de. História do Brasil Nação: A construção nacional (1830-1889). Rio de Janeiro: Objetiva, 2012.

CHIAVERINI, Tatiana. Origem da pena de prisão. Dissertação (Mestrado em Filosofia do Direito). Pontifícia Universidade Católica, São Paulo: 2009.

CRUZ, Ernesto. História de Belém. Coleção Amazônica - Série José Veríssimo. Belém: Universidade Federal do Pará, 1973.

ELIAS, Norbert. O Processo civilizador(Vol.01): uma história dos costumes. Rio de Janeiro: Zahar, 2011.

FERREIRA. Eliana Ramos. Cidade de Malvadezas ou de Matar "Bicudos"? Belém entre a Cabanagem e a Belle Époque. ANPUH - XXV Simpósio Nacional de História - Fortaleza, 2009.

FOUCAULT, Michel. Vigiar e Punir. 40 Ed. Petrópolis - RJ: Vozes, 2012.

FULLER, Claudia Maria. Os Corpos de Trabalhadores e a organização do trabalho livre na província do Pará (1838-1859). Revista Mundos do Trabalho, vol. 3, n. 6, julho-dezembro de 2011, p. 52-66.

GINZBURG, Carlo. Medo, reverência e terror. São Paulo: Cia das Letras, 2014.

KIDDER, Daniel P. Reminiscências de Viagens e Permanências no Brasil, Compreendendo Notícias Históricas e Geográficas do Império e das Diversas Províncias. São Paulo: Livraria Martins Editora; EDUSP, 1972.

MATOS, Ilmar Rohloff de. O Tempo saquarema: a formação do estado imperial. São Paulo: HUCITEC, 2004.

NETO, Flávio de Sá Cavalcanti Albuquerque. A Reforma Prisional no Recife oitocentista: da cadeia à casa de detenção (1830 - 1874). Dissertação (mestrado) - Universidade Federal de Pernambuco. CFCH. História, 2008.

OLIVEIRA, Fernanda Amaral. Os modelos penitenciários no século XIX. Seminário Nacional de História da Historiografia: historiografia brasileira e modernidade, ocorrido na cidade de 
Mariana MG entre os dias 01 a 03 de agosto de 2007. Disponível em: <http://www.ufjf.br/virtu/files/2010/05/artigo-6-a-1.pdf>

OLIVEIRA, Odete Maria. Prisão: um paradoxo social. Florianópolis: UFSC, 1996

PEREIRA, Ana Maria de Souza. "A liberdade confiscada: um olhar histórico sobre os presos e as prisões em Belém". In: BEZERRA NETO, José Maia \& GUZMÁN, Décio de Alencar (Org.). Terra Matura: historiografia e história social da Amazônia. Belém: Paka-tatu, 2002. Pp. 291-310.

REGO, Isabel Pojo. Sociologia da prisão. Soc. estado. vol.19 no.1 Brasília Jan./June 2004. Disponível em: $\quad$ http://www.scielo.br/scielo.php?script=sci_arttext\&pid=S010269922004000100011>.

RICCI, Magda. Um morto, muitas mortes: a imolação de Lobo de Souza e as narrativas da eclosão cabana. In: NEVES, Fernando Arthur de Freitas \& LIMA, Maria Roseane Pinto. Faces da História da Amazônia. Belém: Paka-Tatu, 2006, pp. 519-544.

. Cabanagem, cidadania e identidade revolucionária: o problema do patriotismo na Amazônia entre 1835 e 1840. Revista Tempo, v. 11, n. 22, p. 5-30, 2007.

- Cabanos, patriotismo e identidade: outras histórias de uma revolução. In: GRINBERG, Keila e SALLES, Ricardo. O Brasil Imperial, vol. II. Rio de Janeiro: Civilização Brasileira, 2011.

. As batalhas da Memória ou a cabanagem para além da guerra. In: SARGES, Maria de Nazaré \& RICCI, Magda Maria de Oliveira (Orgs). Os oitocentos na Amazônia: política, trabalho e cultura. Belém: Editora Açaí, 2013, pp. 45-80.

SÁ, Geraldo Ribeiro de. A prisão dos excluídos: origens e reflexões sobre a pena privativa de liberdade. Juiz de Fora: UFJF, 1996.

SALLES, Vicente. Memorial da Cabanagem: esboço do pensamento político-revolucionário no Grão-Pará. Edições CEJUP, 1992.

WALLACE, Alfred Russel, 1823-1913. Viagens pelos Rios Amazonas e Negro. Tradução Eugenio Amado; apresentação Mário Guimarães Ferri. - Belo Horizonte: Ed. Itatiaia; São Paulo: Ed. da Universidade de São Paulo, 1979.

\section{FONTES}

Biblioteca Pública do Estado do Pará "Arthur Viana” / Seção de Microfilmagens. Jornal Treze de Maio.

Prospecto 1305 1840, p. 1.

Avisos 2201 1845, p. 3.

Avisos 1202 1845, p. 4.

Avisos 1502 1845, p. 3.

Avisos 0504 1845, p. 4.

\section{Relatórios dos Presidentes da Província}

PARÁ, Governo. Relatório do Presidente da província do Gram-Pará, o Exm. Sr. José Joaquim Machado D'Oliveira, no dia 3 de dezembro de 1833. Pará, Typ. Do Corrêa, 1833. PARÁ, Governo. Discurso recitado pelo exm. Sr. Soares D'andrea, presidente da província, do Gram-Pará, na abertura da primeira sessão da Assembleia Provincial no dia 2 de março de 1838. Pará, Typ. de Santos e Santos Menor, 1838. 
PARÁ, Governo. Discurso recitado pelo exm. Sr. Bernardo de Souza Franco, presidente da província do Gram-Pará, na abertura da Assembleia Legislativa Provincial no dia 15 de agosto de 1839. Pará, Typ. de Santos \&. Menor, 1839.

PARÁ, Governo. Discurso recitado pelo exm. Sr. João Antonio de Miranda, presidente da província do Pará, na abertura da Assemblea Legislativa Provincial no dia 15 de Agosto de 1840. Pará, typ. de Santos \& Menor, 1840.

PARÁ, Governo. Discurso recitado pelo exm. Sr. Bernardo de Souza Franco, presidente da província do Gram-Pará, na abertura da Assembleia Legislativa Provincial no dia 14 de abril de 1841. Pará, Typ. de Santos \&. Menor, 1841.

PARÁ, Governo. Discurso recitado pelo exm. Sr. Bernardo de Souza Franco, vice-presidente da província do Gram-Pará, na abertura da Assembleia Legislativa Provincial no dia 15 de abril de 1842. Pará, Typ. de Santos \&. Menor, 1842.

PARÁ, Governo. Discurso recitado pelo exmo. Snr. Coronel Jozé Thomaz Henriques, presidente da Província do Pará, na abertura da segunda sessão da Assembleia Legislativa Provincial no dia 15 de agosto de 1843. Pará, typ. de Santos e Menores, 1843.

PARÁ, Governo. Discurso recitado pelo exm. Sr. Desembargador Manuel Paranhas da Silva Vellozo, presidente da Província do Pará, na abertura da primeira sessão da quarta legislativa da Assemblea Provincial no dia 15 de Agosto de 1844. Pará, typ. de Santos e Menores, 1844.

PARÁ, Governo. Índice ou repertório geral das leis da assembleia legislativa provincial do Gram Pará (1838-1853). Por André Curcino Benjamim (Chefe de secção da thezouraria de fazenda da mesma província), 1854.

Disponíveis em: http://brazil. crl.edu.br

Código Criminal do Império Brasileiro - Lei de 16 de dezembro de 1830. Disponível em: <http://www.planalto.gov.br/ccivil_03/leis/LIM/LIM-16-12-1830.htm>.

Reformulação do Código Criminal - Lei $\mathrm{N}^{\circ}$ 261, de 3 de Dezembro de 1841. Disponível em: 〈http://www.planalto.gov.br/ccivil_03/leis/LIM/LIM261.htm> 